\title{
OECD/DAC 분쟁취약국지원네트워크 회의
}

제 4차 분쟁취약국지원네트워크(INCAF) 전체회의가 $\mathrm{OECD}$ 본부에서 개최됨. 동 회의에서는 취약국지원 원칙(Fragile States Principles; FSP)이행 조사계획, 2011-2012 INCAF PWB, 취약국 재정지원 가이드 라인 등의 주제가 논의된 바, 주요 내용은 아래와 같음.

\section{I. 회의 개요}

1. 일시 : 2010년 12월 2일 3일

2. 주제 : 취약국지원원칙(Fragile States Principles; FSP)이행 조사계획, 2011-2012 INCAF $\mathrm{PWB}$, 취약국 재정지원 가이드라인

\section{II. 요지}

1. 분쟁취약지원 관련 가이드라인 및 정책권고 발간 예정

1) 기한 : 금년 내

2) 발간물의 명세

(1) 분쟁취약국의 국가재건, 분쟁방지 및 평화구축 지원 가이드라인

(2) 국제공약 이행평가결과에 기초한 정책권고

(3) 안보시스템 혁신 DAC Handbook 및 무장폭력감소 가이던스 활용 교훈 


\section{2. 취약국 지원원칙(Fragile States Principles; FSP) 이행평가 2차 조사 계획}

1) 시기 : 2011년 상반기 중

2) 대상 : 14 개 분쟁취약 수원국 및 공여국

\section{INCAF의 2011-2012 핵심활동분야 제시}

(1) 평화구축 및 국가재건 관련 가이드라인 및 권고안 생산

(2) 재정지원 및 원조형태 관련 가이드라인 마련

(3) INCAF 가이드라인 이행 평가

(4) 분쟁취약 이슈 논의 활성화

\section{4. 향후 계획}

2011년 제 4차 원조효과고위급회의(HLF-4)에 분쟁취약국 지원이슈를 중심의제로 반영하기 위한 노력을 기울이기로 함.

\section{III. 평가}

O INCAF에서는 분쟁취약국 이슈를 $\mathrm{HLF}-4$ 핵심의제 또는 정치적 토론 주제로 상정시키기 위한 준비작업으로 내년 상반기 중 취약국 지원원칙(FSP) 등 그간 생산한 가이드라인 및 정책권고 등에 대한 공여국들의 이행현황을 본격적으로 평가할 계획이며 한국도 평가대상에 속하는 바, 설문내용 파악 등 동 평가에 대한 구체적 준비와 아울러 분쟁취약국 지원사업의 계획 및 집행 단계에서 관련 국제규범을 적용시키는 노력을 지속적으로 기울여야 할 것으로 보임.

O INCAF의 2011-2012 사업계획의 초점이 분쟁취약관련 신규 가이드라인 생산 및 이행평가에 있 는 만큼 한국도 동 국제원조규범 형성 및 평가과정에 참여하여 입장을 적극적으로 반영시킬 필 요가 있음. 